\title{
Antimutagenic bis (2-ethylhexyl) phthalate isolated from octopus (Paraoctopus vulgaris)
}

\author{
Susana-Gabriela CRUZ-RAMÍREZ ${ }^{1}$ (D) , Carmen-María LÓPEZ-SAIZ ${ }^{1}$, Ema-Carina ROSAS-BURGOS ${ }^{1}$, \\ Francisco-Javier CINCO-MOROYOQUI ${ }^{1}$, Carlos VELÁZQUEZ ${ }^{2}$, Javier HERNÁNDEZ ${ }^{3}$, \\ Armando BURGOS-HERNÁNDEZ ${ }^{1 *}$
}

\begin{abstract}
In the present study, the antimutagenic activity of methanolic (MP) and hexanic (HP) phase from hexane-soluble extract of Paraoctopus vulgaris was evaluated. The HP showed significant concentration-dependent antimutagenic activity $(p<0.05)$ in the Ames assay against aflatoxin $\mathrm{B}_{1}\left(\mathrm{AFB}_{1}\right)$ using Salmonella typhimurium TA98 and TA100 tester strains. Seven fractions (F1-F7) were obtained from HP by silica gel-column chromatography and the antimutagenic activity of F6 and F7 caused significant reduction $(p<0.05)$ in the number of $\mathrm{AFB}_{1}$-induced revertants in both strains. However, high antimutagenic activity was exhibited in TA98 strain (85-97\% reversion inhibition) and remained at a fraction-concentration of $3 \mu \mathrm{g} / \mathrm{mL}$. F6 and F7 composition was analyzed by high-performance liquid chromatography/photodiode array, both fractions shared one peak at $9.42 \mathrm{~min}$ suggesting presence of the same compound. ${ }^{1} \mathrm{H}-\mathrm{NMR}$ and ${ }^{13} \mathrm{C}-\mathrm{NMR}$ analysis results indicate that the bioactive compound is bis (2-ethylhexyl) phthalate. Based on of these results bis (2-ethylhexyl) phthalate exhibit antimutagenic activity, which allows to consider it for further investigation as a potential chemopreventive compound.
\end{abstract}

Keywords: Paraoctopus vulgaris; chemopreventive; antimutagenic; bis (2-ethylhexyl) phthalate.

Practical Application: Bis (2-ethylhexyl) phthalate was isolated from octopus, results suggest a potential for further research in order to be proposed as a chemotherapeutic agent at early stages of carcinogenesis.

\section{Introduction}

The morbidity and mortality due to cancer incidence has increased in the last years. According to the International Agency for Research on Cancer (IARC), in 2012, there was approximately 8.2 million of cancer deaths in the world: 4.7 million (57\%) were males and 3.5 million (43\%) females). Projections to year 2030 suggest that the global cancer burden is expected to increase up to 21.4 million of new cancer cases and 13.2 million cancer deaths (Ferlay et al., 2013).

It is estimated that more than one half of all cancer cases and deaths worldwide are potentially preventable and one strategy with enormous potential of use to deal with this issue is chemoprevention (American Cancer Society, 2011). A number of natural agents present in foods such as, flavonoids, carotenoids, isothiocyanates, terpenoids, and omega- 3 fatty acids, have been evaluated for their anticancer effect in early stages of carcinogenesis (Vidak et al., 2015; Lawson et al., 2015; Li et al., 2016; López-Saiz et al., 2014; Rovito et al., 2013). However, the oceanic environment has been recognized as a wide source of natural bioactive compounds with pharmacological potential and possible future applications (Montaser \& Luesch, 2011).

Marine invertebrates, especially cephalopods, constitute an important source of many biological substances with antioxidant, antitumor, antileukemic, antibacterial, and antiviral activities
(Sudhakar \& Nazeer, 2015; Jesy et al., 2014; Jayaraj et al., 2008; Rajaganapathi et al., 2000). In particular, Paraoctopus limaculatus has been reported as a source of bioactive agents since the isolation of extracts with chemopreventive activity has previously been carried out (Cruz-Ramírez et al., 2015), suggesting the presence of antimutagenic and antiproliferative hexane-soluble compounds. Therefore, the aims of this study were to chemical and structurally characterize the antimutagenic compounds present in the hexane-soluble fraction of octopus tentacles.

\section{Materials and methods}

\subsection{Extraction of bioactive compounds}

Octopus (Paraoctopus vulgaris) specimens were obtained from Bahía de Kino, Sonora, México (29 22’ 27” N, $112^{\circ} 34^{\prime} 08^{\prime \prime}$ O). Tentacles were chopped up, separated in homogeneous portions and freeze-dried at $-30{ }^{\circ} \mathrm{C}$ under vacuum (Unitop 600L, USA).

The compounds isolated from the hexane soluble fraction (HSF), previously reported by Cruz-Ramírez et al. (2015), were partitioned in methanol/hexane (1:1 v:v proportion) for $24 \mathrm{~h}$ at $4{ }^{\circ} \mathrm{C}$. The resulting methanolic (MP) and hexanic (HP) phases were physically separated and the solvents were evaporated. Both phases were evaluated by antimutagenic assay. 


\subsection{Isolation of bioactive compounds by column chromatography}

Since HP was found to be the fraction with the highest antimutagenic activity, it was subjected to open column chromatography with silica gel $(3.5 \mathrm{~cm} \times 90 \mathrm{~cm}$, silica gel, 60-120 mesh, Sigma, St. Louis, MO, USA). HP was fractionated using stepwise gradient elution with hexane: ethyl acetate (99:1-85:5), ethyl acetate: methanol (50:50), and methanol (100) to yield seven fractions (F1-F7). These seven fractions were monitored using thin layer chromatography (TLC) testing plates coated with silica gel and they were revealed using an iodide solution and observed under UV light. Fractions with similar $R f$ values were evaluated for antimutagenic activity using the Ames test.

\subsection{Antimutagenicity assay (Ames test)}

The HP, MP, and seven fractions were evaluated using the mutagenicity assay described by Maron \& Ames (1983), using Salmonella typhimurium TA98 and TA100 tester strains in presence of metabolic activation ( $\mathrm{S} 9 \mathrm{mix}$ ). Fractions were reconstituted and serially diluted with dimethyl sulfoxide (DMSO), and spiked with enough pure $\mathrm{AFB}_{1}$ to achieve a final concentration of $500 \mathrm{ng}$ of $\mathrm{AFB}_{1} / 100 \mu \mathrm{L}$. Seven fractions isolated from HP were evaluated on S. typhimurium TA98 and TA100 strain, at $3000,1000,300$, and $100 \mu \mathrm{g} / \mathrm{mL}$.

Bis (2-ethylhexyl) phthalate was the antimutagenic compound identified in F6 and F7 and these were evaluated with S. typhimurium TA100 using sodium azide as mutagen at 5000,1000,500, and $100 \mathrm{ng} / \mathrm{mL}$. The results were determined in terms of the inhibition of sodium azide and $\mathrm{AFB}_{1}$-induced revertants/ plate for each dilution. All assays were performed by triplicate.

\subsection{RP-HPLC analysis}

Composition of fractions F6 and F7 was analyzed using an Agilent Technologies 1260 Infinity ultra-high-performance liquid chromatograph equipped with a photodiode detector. A $20-\mu \mathrm{L}$ aliquot of sample was injected into a Zorbax Eclipse XDB-C18 semi-preparative column ( $5 \mu \mathrm{m}$ particle size, $250 \times 9.4 \mathrm{~mm}$ i.d.). Mobile phase composition and elution gradients employed at times zero and 23 min were 90A:10B and $0 \mathrm{~A}: 100 \mathrm{~B}$, respectively. Eluent A: ethyl-acetate (HPLC grade); eluent B: hexane (HPLC grade). A $20-\mu \mathrm{L}$ aliquot was injected at a temperature of $20^{\circ} \mathrm{C}$. Elution of $\mathrm{F} 6$ and $\mathrm{F} 7$ constituents were monitored measuring their absorption at $350 \mathrm{~nm}$ and scanned $(190$ to $600 \mathrm{~nm})$ to detect maximum absorption values.

\section{$2.5{ }^{1} \mathrm{H}-\mathrm{NMR}$ and ${ }^{13} \mathrm{C}-\mathrm{NMR}$}

Antimutagenic fractions F6 and F7 were analyzed using a Bruker NMR spectrometry equipment operated at $400 \mathrm{MHz}$ (Billerica, MA, USA). Each fraction was dissolved in $\mathrm{CDCl}_{3}(500 \mu \mathrm{L}$; Sigma-Aldrich, Saint Louis, MI, USA) with a small amount of tetramethylsilane (TMS).

\subsection{GC-MS}

GC-MS analysis was performed using a JMS-GCmatell-GC-MS SYSTEM. Fractions 6 and 7 were injected into the column (HP-5MS 5\%-phenyl-methylpolysiloxane, $30 \mathrm{~m} \times 0.25 \mathrm{~mm} \times 0.25 \mu \mathrm{m}$, Agilent 19091S-433); elution of components was performed at a flow rate of $1 \mathrm{~mL} / \mathrm{min}$. The injector temperature was $310^{\circ} \mathrm{C}$ and the initial temperature $\left(40^{\circ} \mathrm{C}\right)$ was maintained for $1 \mathrm{~min}$ followed by a ramp of $8{ }^{\circ} \mathrm{C} / \mathrm{min}$ to $310^{\circ} \mathrm{C}$. The ionization voltage was $70 \mathrm{eV}$. The identification of compounds was done using the database of National Institute Standard and Technology (NIST, 2016) comparing the mass spectrum obtained with the spectrum of the known components stored in the NIST library.

\subsection{Statistical analysis}

The statistical analysis was performed using the JMP statistical software (visual statistical discovery software, 10). Data were analyzed using an ANOVA followed by a Tukey-Kramer test $(p<0.05)$.

\section{Results and discussion}

\subsection{Antimutagenic assay}

Figure 1 shows the antimutagenic activity of hexanic (HP) and methanolic (MP) phases obtained from the hexanic soluble fraction (HSF) of octopus tentacle, previously reported by
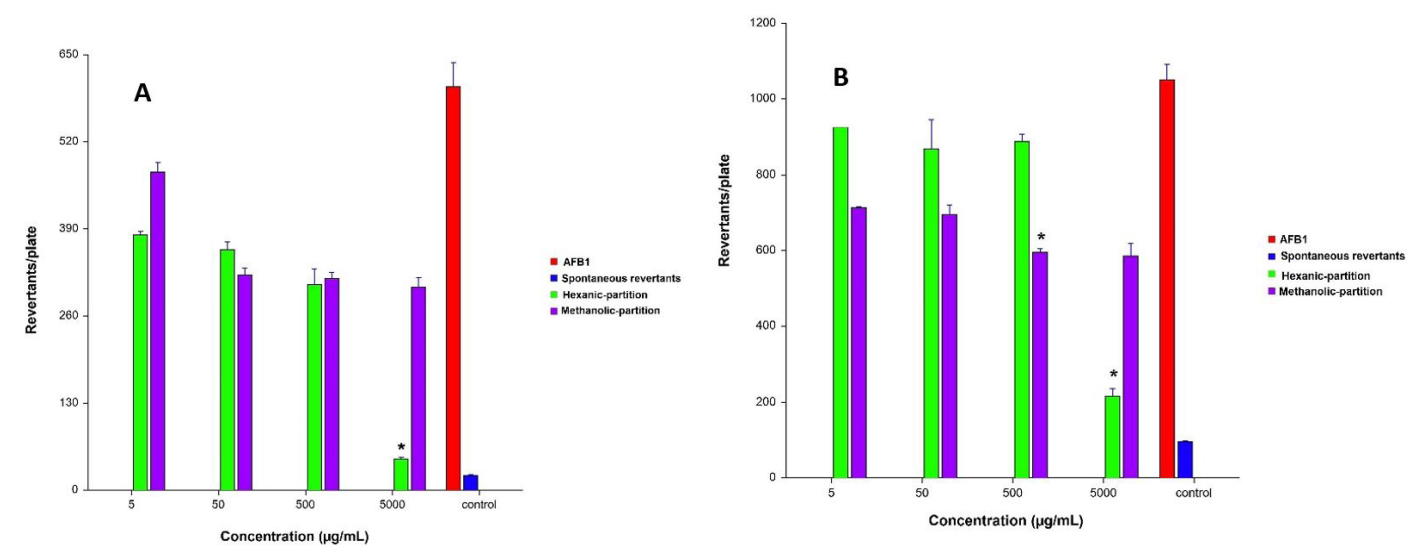

Figure 1. Antimutagenic activity of hexanic and methanolic partition against $\mathrm{AFB}_{1}$ induced mutation in Salmonella typhimurium strain (A) TA98; (B) TA100 $\left({ }^{*} p<0.05\right)$. 
Cruz-Ramírez et al. (2015). The HP, at $5000 \mu \mathrm{g} / \mathrm{mL}$, exhibited the highest antimutagenic effect for TA98 and TA100 strains tested in the presence of $S 9$. The reduction of the mutagenicity induced by $500 \mathrm{ng}$ of $\mathrm{AFB}_{1}$ in TA100 strain, at the presence of $500 \mu \mathrm{g} / \mathrm{mL}$ of MP, was statistically different $(p<0.05)$ from that observed when same concentration of HP was used. Even though the decrease in the number of revertant/plate, due to the presence of either HP or MP seemed to be concentration-dependent for both strains, no statistical differences $(p>0.05)$ were observed at the two lowest concentrations. These data suggested that the HP contents might protect DNA from damage induced by $\mathrm{AFB}_{1}$. Recent studies have found that hexane extract from plants (Astragalus species) showed antimutagenic activity against sodium azide and 9-aminoacridine using Salmonella typhimurium TA1535 and TA1537 tester strains. The mutation inhibition was higher in TA1537 (susceptible to frame-shift type of mutation) than in TA1535 (susceptible to single base-substituted type of mutation) (Gulluce et al., 2010). Similarly, the results in the present study show that HP contains antimutagenic compounds capable of protecting DNA from both types of mutation events, base-pair substitution (TA100) and frame-shifts (TA98). A chemopreventive effect of a hexanic extract from the marine algae Chondria dasyphylla was reported by Khanavi et al. (2012), finding evidences of cytotoxic activity against the proliferation of T47D cells. Also, they found that the hexane soluble fraction of Sargassum angustifolium showed antiproliferative activity in T47D and HT-29 cell lines.

Results from the antimutagenic assay performed on the fractions obtained from HP by column chromatography are shown in Table 1. Seven fractions were eluted and their antimutagenic activity was found to be concentration-dependent.

Table 1. Antimutagenic activity of fractions of hexanic partition (HP) against $\mathrm{AFB}_{1}$ induced mutation in Salmonella typhimurium strain.

\begin{tabular}{|c|c|c|c|c|}
\hline \multirow{2}{*}{$\begin{array}{l}\text { Extract } \\
\text { fraction } \\
\end{array}$} & \multicolumn{4}{|c|}{ Concentration $(\mu \mathrm{g} / \mathrm{mL})$} \\
\hline & 3000 & 300 & 30 & 3 \\
\hline \multicolumn{5}{|l|}{ TA98 } \\
\hline F1 & $390 \pm 30^{\mathrm{b}}$ & $636 \pm 53^{a}$ & $952 \pm 36^{\mathrm{a}}$ & $1012 \pm 85^{\mathrm{ab}}$ \\
\hline $\mathrm{F} 2$ & $478 \pm 20^{\mathrm{a}}$ & $660 \pm 50^{\mathrm{a}}$ & $907 \pm 48^{\mathrm{a}}$ & $982 \pm 26^{b c}$ \\
\hline F3 & $172 \pm 21^{\mathrm{cd}}$ & $728 \pm 59^{\mathrm{a}}$ & $718 \pm 44^{\mathrm{b}}$ & $1030 \pm 87^{a}$ \\
\hline $\mathrm{F} 4$ & $141 \pm 4^{\mathrm{de}}$ & $365 \pm 44^{\mathrm{b}}$ & $571 \pm 41^{\mathrm{c}}$ & $862 \pm 13^{c}$ \\
\hline F5 & $198 \pm 13^{c}$ & $295 \pm 22^{\mathrm{bc}}$ & $359 \pm 23^{\mathrm{d}}$ & $645 \pm 6^{\mathrm{d}}$ \\
\hline F6 & $86 \pm 9^{e}$ & $145 \pm 10^{\mathrm{d}}$ & $186 \pm 33^{e}$ & $237 \pm 38^{e}$ \\
\hline F7 & $110 \pm 9^{\mathrm{e}}$ & $166 \pm 7^{c d}$ & $154 \pm 6^{\mathrm{e}}$ & $187 \pm 19^{\mathrm{e}}$ \\
\hline \multicolumn{5}{|l|}{ TA100 } \\
\hline F1 & $1595 \pm 72^{\mathrm{A}}$ & $2192 \pm 50^{\mathrm{A}}$ & $2207 \pm 71^{\mathrm{A}}$ & $2066 \pm 66^{\mathrm{AB}}$ \\
\hline $\mathrm{F} 2$ & $1638 \pm 69^{A}$ & $2029 \pm 81^{\mathrm{B}}$ & $2107 \pm 65^{\mathrm{A}}$ & $2137 \pm 56^{\mathrm{AB}}$ \\
\hline F3 & $1906 \pm 86^{\mathrm{A}}$ & $2063 \pm 53^{\mathrm{AB}}$ & $2201 \pm 47^{\mathrm{A}}$ & $2208 \pm 69^{A}$ \\
\hline $\mathrm{F} 4$ & $456 \pm 43^{\mathrm{B}}$ & $724 \pm 34^{\mathrm{C}}$ & $1533 \pm 67^{C}$ & $2092 \pm 42^{\mathrm{AB}}$ \\
\hline F5 & $525 \pm 88^{\mathrm{B}}$ & $781 \pm 94^{\mathrm{C}}$ & $1071 \pm 23^{\mathrm{D}}$ & $1610 \pm 45^{\mathrm{C}}$ \\
\hline F6 & $282 \pm 26^{\mathrm{B}}$ & $798 \pm 14^{\mathrm{C}}$ & $1854 \pm 29^{\mathrm{B}}$ & $1975 \pm 38^{\mathrm{B}}$ \\
\hline F7 & $296 \pm 70^{\mathrm{B}}$ & $654 \pm 29^{C}$ & $1523 \pm 54^{\mathrm{C}}$ & $1786 \pm 54^{\mathrm{C}}$ \\
\hline
\end{tabular}

Positive control $\mathrm{AFB}_{1}$ (500 ng/plate) induced $1302 \pm 30$ and $2172 \pm 25$ revertants/plate for TA98 and TA100 tester strains, respectively. Spontaneous revertants were $29 \pm 3$ and $234 \pm 20$ for TA98 and TA100 tester strains, respectively. Values are means of three replicates \pm standard error mean. Different letters in a column represent significant differences $(p<0.05)$
Fractions 4, 6, and 7 (yields: 1, 1, and $0.8 \%$ dry base, respectively) showed the lowest reversion rates at $3000 \mu \mathrm{g} / \mathrm{mL}$ concentration $(p<0.05)$ in TA98 tester strain. The inhibition of the AFB mutagenicity in the presence of fractions 6 and 7 remained, even when these fractions were diluted, suggesting a strong antimutagenicity potential at low concentrations of the bioactive compounds present in these fractions. However, the antimutagenic potential tested in the TA100 strain was statistically different $(p<0.05)$ among fractions $4,5,6$, and 7 at $3000 \mu \mathrm{g} / \mathrm{mL}$. Recently, Cano-Campos et al. (2011) isolated antimutagenic compounds from the hexane-soluble fraction obtained from Randia echinocarpa fruit. They reported high percentage of inhibition of the mutation (> $76 \%$ ) induced by 1-nitropyrene in Salmonella typhimurium YG1024 tester strain.

Hence, these results showed that fractions 6 and 7 maintain their antimutagenic activity at the lowest concentrations tested in TA98 strains. These fractions were subjected to partial characterization by spectrophotometric techniques.

\subsection{RP-HPLC}

The chromatogram and UV-Vis absorption spectrum obtained by RP-UHPLC of fractions F6 and F7 are shown in Figure 2. Both fractions showed one major peak at a retention time of $9.42 \mathrm{~min}$, which suggests that the compound responsible of the antimutagenic activity had been parted in both fractions. Both fractions showed absorption in the range of near UV (Figure 2A and 2B) which suggest the presence of compounds containing conjugated double-bond systems.

The presence of conjugated double bond systems in compounds such polyunsaturated fatty acids have been evaluated by Kim et al. (2011). These authors reported hexane-soluble bioactive lipids from Mytilus coruscus. Also, they found that these bioactive lipids possess anti-tumour effects by inducing apoptosis in human prostate cancer cells. Based on the above, the presence of compounds containing conjugated double bond systems in their structure is not discarded for fractions 6 and 7.

\subsection{Characterization ${ }^{1} \mathrm{H}-\mathrm{NMR}$ and ${ }^{13} \mathrm{C}-\mathrm{NMR}$}

Figure $3 \mathrm{~A}$ shows ${ }^{1} \mathrm{H}-\mathrm{NMR}$ spectrum for fractions $\mathrm{F} 6$ and $\mathrm{F} 7$ which evidence similar signals between $\delta_{\mathrm{H}}$ 7.5-7.8 corresponding to protons of aromatic ring system, signals between $\delta_{\mathrm{H}} 4.1-4.3$ were associated to protons adjacent to carbons attached to oxygen atoms in ester bonds. Chemical shifts observed between 0.9-2.0 are attributed to methine, methyl, and methylene protons of aliphatic chain of phthalate. The ${ }^{13} \mathrm{C}-\mathrm{NMR}$ analysis (Figure $3 \mathrm{~B}$ ) showed signals between $\delta=13.16$ and $29.32 \mathrm{ppm}$, which are attributed to aliphatic carbons. The chemical shift observed at $\delta=67 \mathrm{ppm}$ is evidence of a carbon involved in a $\mathrm{C}-\mathrm{O}$ bond, and signals $\delta=127-129 \mathrm{ppm}$ are associated to aromatic ring carbons. Finally, the signal of carbonyl function group present in an ester bond was observed at $\delta=170 \mathrm{ppm}$. All these results are consistent with the chemical structure of phthalate esters and the presence of this type of compound in marine organisms has been previously reported by Moushumi Priya \& Jayachandran (2012) and the isolation of bis (2-ethylhexyl) phthalate from marine Bacillus pumilus MB 40 which was found to induce apoptosis and arrest of the cell 

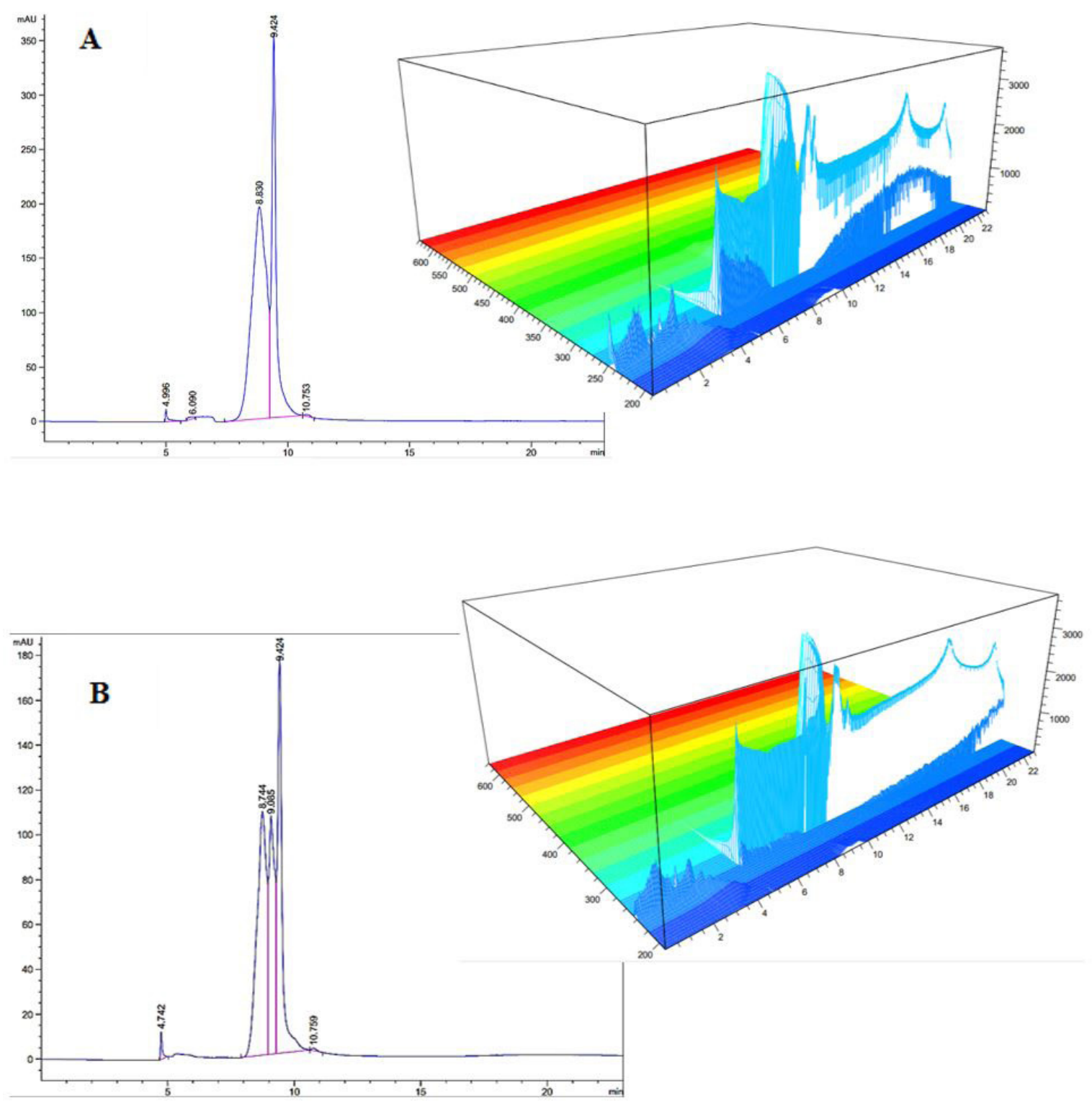

Figure 2. RP-HPLC chromatogram and spectrum of (A) 6 and (B) 7 fraction with antimutagenic activity.

cycle at a sub G0/G1 phase in human erytroleukemic K562 cells. All of this suggested that the bioactive compound(s) responsible for the antimutagenic activity of fractions F6 and F7 might be bis (2-ethylhexyl) phthalate. In order to confirm this approach, GC/MS analyses were carried out.

\subsection{GC/MS}

The results of GC-MS analysis of fractions F6 and F7 confirmed the presence of four compounds (Figure 4A) with retention times of 19.47, 23.79, 26.03, and $26.13 \mathrm{~min}$. In terms of $\mathrm{m} / \mathrm{z}$ ratio and \% peak area, the results revealed: $\mathrm{m} / \mathrm{z}=43(3.7 \%)$, $\mathrm{m} / \mathrm{z}=149(99.6 \%), \mathrm{m} / \mathrm{z}=59(3.6 \%)$, and $\mathrm{m} / \mathrm{z}=185(10.9 \%)$. Individual mass fragmentation (Figure $4 \mathrm{~B}$ ) of the main $(99.6 \%$ abundance) compound produced $\mathrm{m} / \mathrm{z}=113, \mathrm{~m} / \mathrm{z}=279, \mathrm{~m} / \mathrm{z}=167$, and $\mathrm{m} / \mathrm{z}=149$ ions, is consistent with NIST library (National
Institute of Standards and Technology, 2016). The molecular weight shown 390 and molecular formula indicated $\mathrm{C}_{24} \mathrm{H}_{38} \mathrm{O}_{4}$, these results confirmed the presence of bis (2-ethylhexyl) phthalate.

The structure-activity relationship (SAR) of antimutagenic compounds has been previously studied (Kakinuma et al., 1986; Menon et al., 1999). Based on previous reports on antimutagenic activity, ester-phthalates have been associated to their capability to operate as Michael acceptors within the cell. Thus, the presence of carbonyl group in bis (2-ethylhexyl) phthalate might represent a good nucleophilic site in living systems; therefore, these compounds may act primarily via bioantimutagenic or desmutagenic mechanism. Desmutagen mechanism of bis (2-ethylhexyl) phthalate could be associated to its capability of acting as a nucleophile against an electrophilic promutagen 8,9-dihydro-8-(N7-guanyl)-9-hydroxy-aflatoxin $\mathrm{B}_{1}$ adduct and prevent the initial DNA damage. 
$\mathbf{A}$
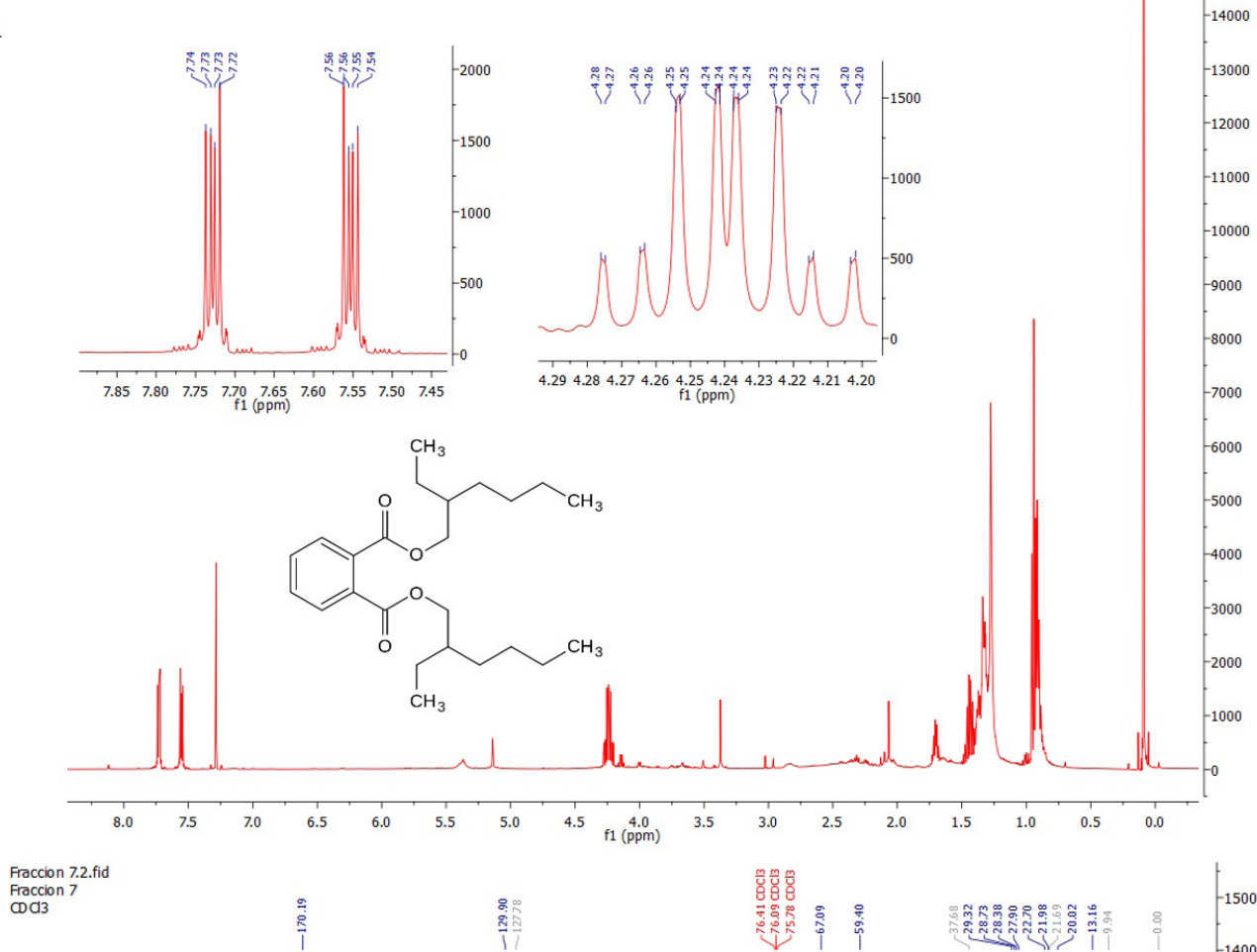

B

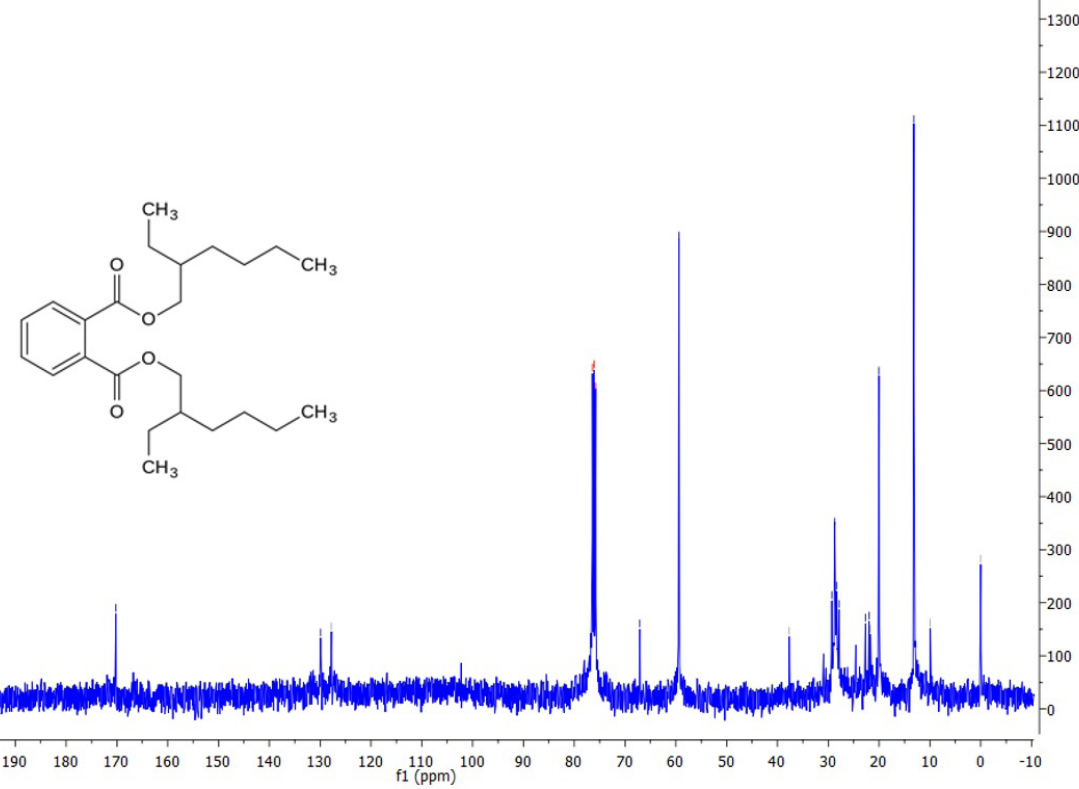

Figure 3. Spectrum (A) ${ }^{1} \mathrm{H}-\mathrm{NMR}$ and $(\mathrm{B}){ }^{13} \mathrm{C}-\mathrm{NMR}$ of antimutagenic fraction $\mathrm{F} 6$ and $\mathrm{F} 7 \mathrm{in} \mathrm{CDCl}_{3}$. Chemical shifts $(\delta)$ are in ppm.

\subsection{Antimutagenic activity of bis (2-ethylhexyl) phthalate}

Figure 5 shows the antimutagenic effect of commercially (sigma-Aldrich, USA) bis (2-ethylhexyl) phthalate on the mutagenicity of $500 \mathrm{ng}$ of $\mathrm{AFB}_{1}$. A reduction in the number of revertants/plate were observed for 5000 and $1000 \mathrm{ng} / \mathrm{mL}$ and represent 60 and $51 \%$ inhibition of sodium azide-induced mutations, respectively.

Statistically, mutation inhibition caused by 5000 and $1000 \mathrm{ng} / \mathrm{mL}$ was significantly $(p<0.05)$ different from that observed for 500 and $100 \mathrm{ng} / \mathrm{mL}$. These results are in accordance with those previously reported by Nakamura et al. (1982); lower dosages of bis (2-ethylhexyl) phthalate $(2.8$ and $28 \mu \mathrm{g} / \mathrm{mL})$ showed $50 \%$ inhibition of the mutation induced by $4-\mathrm{NQO}$ and MNNG in V79 hamster cells. Furthermore, Lee et al. (2000) found that bis (2-ethylhexyl) phthalate decreased the number of revertants/plate in tester strains exposed to AF-2 at concentrations between 100-1 $\mu \mathrm{g} /$ plate, doses-response type of relationships obtained evidenced high percentages of antimutagenic activity $(>46 \%)$ as evaluated in S. typhimurium TA98 and TA100 strains. Finally, bis (2-ethylhexyl) phthalate did not exhibit toxicity at 5000, 1000, 500, and $100 \mathrm{ng} / \mathrm{mL}$ (data not shown) in TA100 strain. 

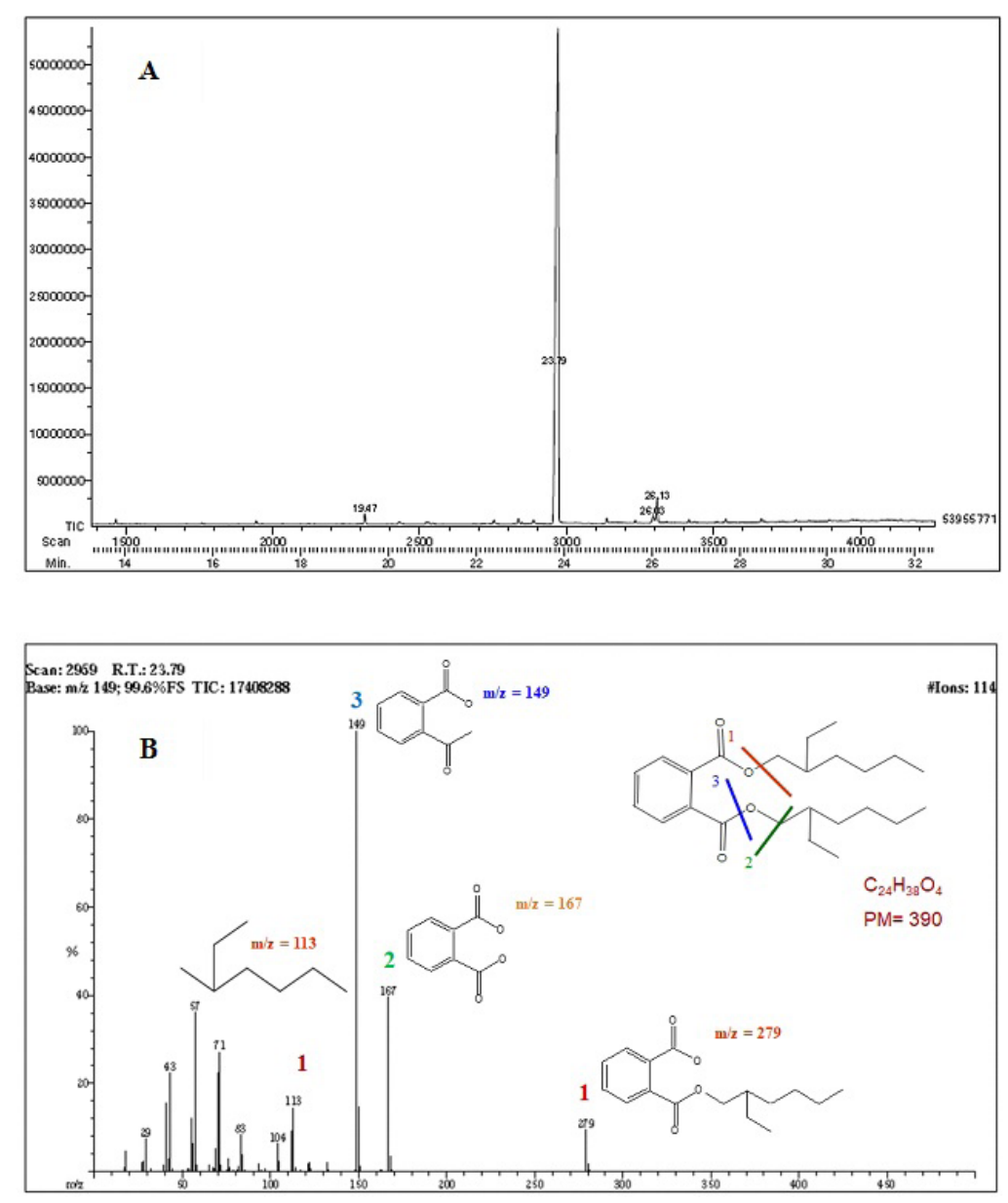

Figure 4. Chromatogram of fractions F6 and F7 (A), mass spectra of peak $23.79 \mathrm{~min}(\mathrm{~B})$.
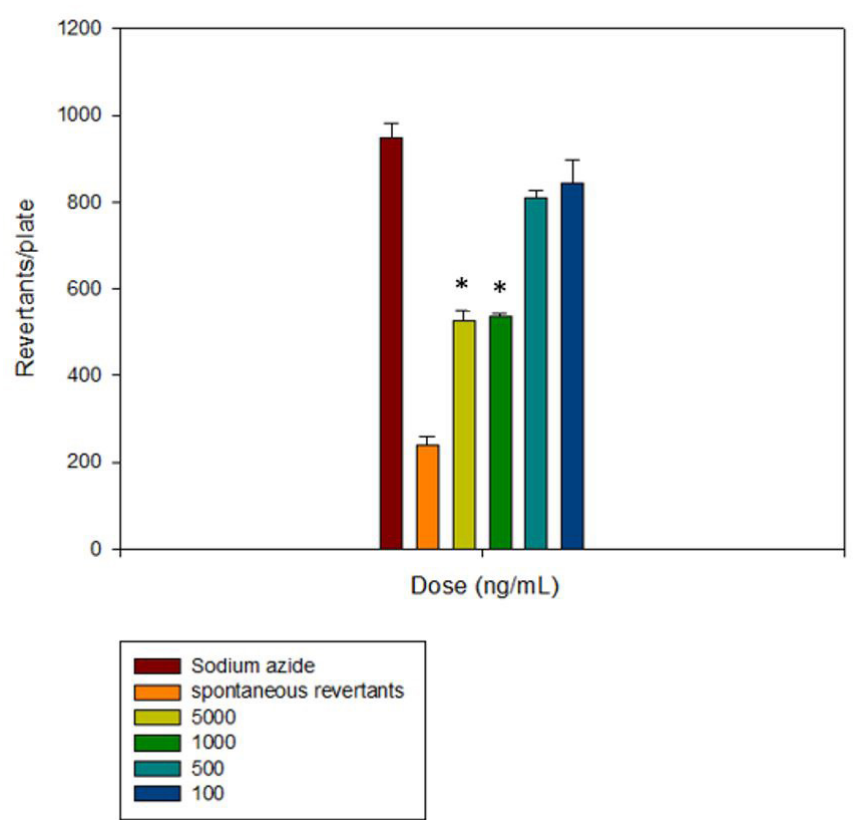

Figure 5. Antimutagenic activity of commercial bis (2-ethylhexyl) phthalate against sodium azide $(1.5 \mu \mathrm{g} / \mathrm{mL})$ induced mutation in Salmonella typhimurium strain TA100. Values are means of three replicates \pm standard error mean. $\left({ }^{*} p<0.05\right)$.
These results suggest the bis (2-ethylhexyl) phthalate is capable of inhibiting both, frame shift and base pair substitution mutations in S. typhimurium tester strains; therefore, this compound might protect DNA from damage caused by both, direct- and indirect-acting mutagens ( $\mathrm{AFB}_{1}$ and sodium azide).

\section{Conclusions}

In conclusion, fractions $\mathrm{F} 6$ and F7, both derived from the hexanic phase of octopus tentacles, are highly antimutagenic in vitro, being bis (2-ethylhexyl) phthalate the potential compound responsible for this bioactivity; however, further investigation is necessary to fully assess its chemopreventive properties.

\section{Acknowledgements}

Authors thank Consejo Nacional de Ciencia y Tecnología (CONACYT) from México for financing project 241133 and the Unidad de Servicios de Apoyo en Resolución Analítica from the Universidad Veracruzana for providing its facilities to carry out part of the present research work. 


\section{References}

American Cancer Society - ACS. (2011). Global cancer facts \& figures (2nd ed.). Atlanta: ACS.

Cano-Campos, M. C., Díaz-Camacho, S. P., Uribe-Beltrán, M. J., LópezAngulo, G., Montes-Avila, J., Paredes-López, O., \& Delgado-Vargas, F. (2011). Bio-guided fractionation of the antimutagenic activity of methanolic extract from the fruit of Randia echinocarpa (Sessé et Mociño) against 1-nitropyrene. Food Research International, 44, 3087-3093. http://dx.doi.org/10.1016/j.foodres.2011.08.006.

Cruz-Ramírez, S. G., Lopéz-Saiz, C. M., Rosas-Burgos, E. C., CincoMoroyoqui, F. J., Velázquez, C., Hernández, J., \& Burgos-Hernández, A. (2015). Antimutagenic, antiproliferative, and antioxidant effect of extracts obtained from octopus (Paraoctopus limaculatus). Food Science and Technology, 35(4), 722-728. http://dx.doi.org/10.1590/1678457X.0001.

Ferlay, J., Shin, H. R., Bray, F., Forman, D., Mathers, C. D., \& Parkin, D. (2013). Cancer incidence and mortality worldwide (IARC Cancer Base, No. 11). Lyon: International Agency for Research on Cancer. Retrieved from http://globocan.iarc.fr

Gulluce, M., Agar, G., Baris, O., Karadayi, M., Orhan, F., \& Sahin, F. (2010). Mutagenic and antimutagenic effects of hexane extract of some Astragalus species grown in the eastern Anatolia region of Turkey. Phytotherapy Research, 24(7), 1014-1018. PMid:19957249.

Jayaraj, S. S., Thiagarajan, R., Arumugam, M., \& Mullainadhan, P. (2008). Isolation, purification -and characterization of [beta]-1,3glucan binding protein from the plasma of marine mussel Perna viridis. Fish \& Shellfish Immunology, 24(6), 715-725. http://dx.doi. org/10.1016/j.fsi.2007.11.012. PMid:18420422.

Jesy, J. H., Thilaga, R. D., \& Mary, J. (2014). Anticancer activity of marine cephalopod (S.Pharaonis) from Gulf of mannar. International Journal of Current Research, 6(11), 10009-10012.

Kakinuma, K., Koike, J., Ishibashi, K., Takahashi, W., \& Takei, H. (1986). Structure-activity relationship and design of an antimutagen against the UV-induced mutation of Escherichia coli. Agricultural and Biological Chemistry, 50(3), 625-631. http://dx.doi.org/10.1271/ bbb1961.50.625.

Khanavi, M., Gheidarloo, R., Sadati, N., Ardekani, M. R., Nabavi, S. M., Tavajohi, S., \& Ostad, S. N. (2012). Cytotoxicity of fucosterol containing fraction of marine algae against breast and colon carcinoma cell line. Pharmacognosy Magazine, 8(29), 60-64. http:// dx.doi.org/10.4103/0973-1296.93327. PMid:22438665.

Kim, E.-K., Kim, Y.-S., Lee, S.-J., Jeon, Y.-J., Ahn, C.-B., \& Kim, Y.-T. (2011). Effect of partially purified lipid from the mussel Mytilus coruscus on apoptosis in cancer cells. Journal of the Korean Society for Applied Biological Chemistry, 54(1), 59-65. http://dx.doi.org/10.3839/ jksabc.2011.008.

Lawson, A. P., Long, M. J. C., Coffey, R. T., Qian, Y., Weerapana, E., El Oualid, F., \& Hedstrom, L. (2015). Naturally occurring isothiocyanates exert anticancer effects by inhibiting deubiquitinating enzymes. Cancer Research, 75(23), 5130-5142. http://dx.doi.org/10.1158/00085472.CAN-15-1544. PMid:26542215.

Lee, K. H., Kim, J. H., Lim, D. S., \& Kim, C. H. (2000). Anti-leukaemic and anti-mutagenic effects of di(2-ethylhexyl) phthalate isolated from Aloe vera Linne. The Journal of Pharmacy and Pharmacology,
52(5), 593-598. http://dx.doi.org/10.1211/0022357001774246. PMid:10864149.

Li, D.-L., Zheng, X., Chen, Y.-C., Jiang, S., Zhang, Y., Zhang, W.-M., Wang, H.-Q., Du, Z.-Y., \& Zhang, K. (2016). Terpenoid composition and the anticancer activity of Acanthopanax trifoliatus. Archives of Pharmacal Research, 39(1), 51-58. http://dx.doi.org/10.1007/ s12272-015-0655-y. PMid:26345267.

López-Saiz, C. M., Velázquez, C., Hernández, J., Cinco-Moroyoqui, F. C., Plascencia-Jatomea, M., Robles-Sánchez, M., Machi-Lara, L., \& Burgos-Hernandez, A. (2014). Isolation and structural elucidation of antiproliferative compounds of lipidic fractions from white shrimp muscle (Litopenaeus vannamei). International Journal of Molecular Sciences, 15(12), 23555-23570. http://dx.doi.org/10.3390/ ijms151223555. PMid:25526568.

Maron, D. M., \& Ames, B. N. (1983). Revised methods for the Salmonella mutagenicity test. Mutation Research, 113(3-4), 173-215. http:// dx.doi.org/10.1016/0165-1161(83)90010-9. PMid:6341825.

Menon, S. R., Patel, V. K., Mitscher, L. A., Shih, P., Pillai, S. P., \& Shankel, D. M. (1999). Structure-antimutagenic activity relationship study of plicatin B. Journal of Natural Products, 62(1), 102-106. http:// dx.doi.org/10.1021/np980304n. PMid:9917292.

Montaser, R., \& Luesch, H. (2011). Marine natural products: a new wave of drugs? Future Medicinal Chemistry, 3(12), 1475-1489. http:// dx.doi.org/10.4155/fmc.11.118. PMid:21882941.

Moushumi Priya, A., \& Jayachandran, S. (2012). Induction of apoptosis and cell cycle arrest by Bis (2-ethylhexyl) phthalate produced by marine Bacillus pumilus MB 40. Chemico-Biological Interactions, 195(2), 133-143. http://dx.doi.org/10.1016/j.cbi.2011.11.005. PMid:22155658.

Nakamura, Y., Fukushima, H., Aoki, N., Tomita, I., Inui, N., \& Tutikawa, K. (1982). Mutagenic and antimutagenic activities of phthalate ester: DEHP. In Proceedings of the 8th Symposium on Environmental Pollutants and Toxicology (Vol. 28, p. 36). Sendai, Japan: Pharmaceutical Society of Japan.

National Institute of Standards and Technology - NIST. (2016). NIST chemistry webbook. Gaithersburg: NIST. Retrieved from http:// webbook.nist.gov/chemistry/

Rajaganapathi, J., Thyagarajan, S. P., \& Edward, J. K. (2000). Study on cephalopod's ink from anti-retroviral activity. Indian Journal of Experimental Biology, 38(5), 519-520. PMid:11272422.

Rovito, D., Giordano, C., Vizza, D., Plastina, P., Barone, I., Casaburi, I., Lanzino, M., De Amicis, F., Sisci, D., Mauro, L., Aquila, S., Catalano, S., Bonofiglio, D., \& Andó, S. (2013). Omega-3 PUFA ethanolamides DHEA and EPEA induce autophagy through PPAR $\gamma$ activation in MCF-7 breast cancer cells. Journal of Cellular Physiology, 228(6), 1314-1322. http://dx.doi.org/10.1002/jcp.24288. PMid:23168911.

Sudhakar, S., \& Nazeer, R. (2015). Preparation of potent antioxidant peptide from edible part of shortclub cuttlefish against radical mediated lipid and DNA damage. Lebensmittel-Wissenschaft + Technologie, 64(2), 593-601. http://dx.doi.org/10.1016/j.lwt.2015.06.031.

Vidak, M., Rozman, D., \& Komel, R. (2015). Effects of flavonoids from food and dietary supplements on glial and glioblastoma multiforme cells. Molecules, 20(10), 19406-19432. http://dx.doi.org/10.3390/ molecules201019406. PMid:26512639. 